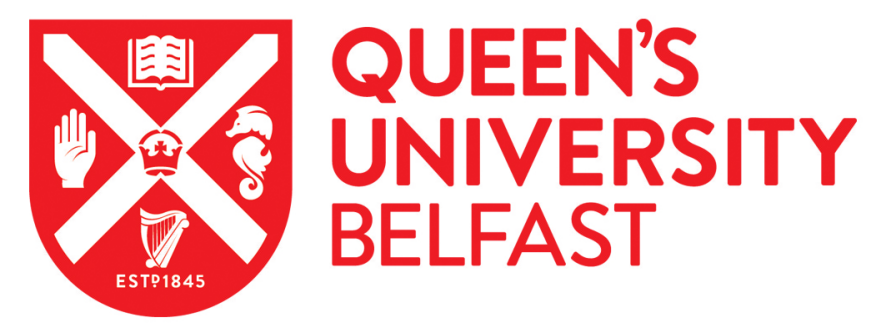

\title{
Do polymorphisms of apoB, LPL or apoE affect the hypocholesterolemic response to weight loss?
}

Kee, F., Young, I., Poirier, O., McMaster, D., Gardner, E., McGeough, J., Patterson, C., Dallongeville, J., Cambien, F., \& Evans, A. (2000). Do polymorphisms of apoB, LPL or apoE affect the hypocholesterolemic response to weight loss? Atherosclerosis, 153(1), 119-128.

Published in:

Atherosclerosis

Queen's University Belfast - Research Portal:

Link to publication record in Queen's University Belfast Research Portal

\section{General rights}

Copyright for the publications made accessible via the Queen's University Belfast Research Portal is retained by the author(s) and / or other copyright owners and it is a condition of accessing these publications that users recognise and abide by the legal requirements associated with these rights.

Take down policy

The Research Portal is Queen's institutional repository that provides access to Queen's research output. Every effort has been made to ensure that content in the Research Portal does not infringe any person's rights, or applicable UK laws. If you discover content in the Research Portal that you believe breaches copyright or violates any law, please contact openaccess@qub.ac.uk. 


\title{
Do polymorphisms of apoB, LPL or apoE affect the hypocholesterolemic response to weight loss?
}

\author{
F. Kee ${ }^{\text {a,* }}$, I.S. Young ${ }^{b}$, O. Poirier ${ }^{\text {c }}$, D. McMaster ${ }^{\text {d }}$, E. McCrum ${ }^{a}$, J. McGeough ${ }^{\text {a }}$, \\ C.C. Patterson ${ }^{a}$, J. Dallongeville ${ }^{\mathrm{e}}$, F. Cambien ${ }^{\mathrm{c}}$, A.E. Evans ${ }^{\mathrm{a}}$ \\ a Department of Epidemiology and Public Health, The Queen's University of Belfast (QUB), Mulhouse Building, Grosvenor Rd., Belfast, \\ Northern Ireland BT12 $6 B J, U K$ \\ ${ }^{\mathrm{b}}$ Department of Clinical Biochemistry, The Queen's University of Belfast (QUB), Mulhouse Building, Grosvenor Rd., Belfast, \\ Northern Ireland BT12 6BJ, UK \\ ${ }^{\mathrm{I}}$ INSERM SC 7 and U525, France \\ d Department of Medicine, The Queen's University of Belfast (QUB), Mulhouse Building, Grosvenor Rd., Belfast, \\ Northern Ireland BT12 6BJ, UK \\ e Insitut Pasteur, Lille, France
}

Received 10 May 1999; received in revised form 11 November 1999; accepted 16 December 1999

\begin{abstract}
To assess whether there is a differential hypocholesterolemic response to weight loss for subjects carrying polymorphisms of the apolipoprotein B and other genes. A before and after comparison of lipid parameters following a calorie controlled diet for an intervention period of 12 weeks. A lipid clinic based in a large teaching hospital. The difference in slope coefficients relating the percentage change in lipid parameters to the change in body weight (adjusted for age, gender and initial body mass index (BMI)), for genotype subgroups defined by polymorphisms of the 5'VNTR apoB gene, two mutations of the LPL gene and ApoE. One hundred and forty six subjects completed the intervention diet. While, on average, the intervention was successful (mean weight loss $3.9 \%$ ), there was no statistically significant difference in the slope coefficients relating lipid change to weight loss for most of the genotypes tested. The slope difference for long versus short $5^{\prime} \mathrm{VNTR}$ alleles of the apoB gene was 0.445 ( $\left.-1.307,2.198\right)$ for apolipoprotein $\mathrm{B}$ and $-0.104(-1.486,1.278)$ for total cholesterol. However, subjects carrying at least one $\varepsilon 4$ allele were significantly hypo-responsive to weight loss, difference in slope coefficients $-1.087(-2.09,-0.084)$ and $-1.320(-2.589$, 0.051) for total cholesterol and apoB, respectively. Although, this study is one of the largest of its kind, it has not replicated the findings of other smaller studies. These findings do not provide support for the use of genotype-targeted dietary advice in routine practice. (c) 2000 Elsevier Science Ireland Ltd. All rights reserved.
\end{abstract}

Keywords: Hypercholesterolemia; Weight loss; Genotype

\section{Introduction}

The contribution of elevated serum cholesterol, smoking and raised blood pressure to the underlying population risk of coronary heart disease (CHD) is now beyond question. What is equally clear, however, is the fact that although these risk factors predict well in groups, they have only modest predictive power at an individual level. Lately, therefore, interest has been

\footnotetext{
* Corresponding author. Tel.: + 44-1232-894614; fax: + 44-1232231907.

E-mail address: f.kee@qub.ac.uk (F. Kee).
}

refocused in the role of genetic factors. Such was the impetus behind Etude Cas-Temoin sur l'Infarctus du Myocarde (ECTIM). This study capitalised on the fact that registration of CHD events under the auspices of the WHO MONICA project, had confirmed a threefold difference in myocardial infarction incidence and mortality between France and Northern Ireland and provided an ideal population sampling frame to study genetic associations with coronary risk.

Within this study, a variety of apoB polymorphisms has been linked to myocardial infarction risk. An intriguing finding was the association of risk with variable-number tandem repeat polymorphisms of the 
apolipoprotein B gene [1]. Subjects carrying the 48-repeat allele were at increased risk of MI but only if they had a high body mass index (BMI). Similar findings have emerged in other studies for different lipid traits. For example, recent results from the European Atherosclerosis Research Study II show a broad parallel with respect to the ASN9 mutation of the lipoprotein lipase gene [2]. In that study, cases were the 'healthy' sons of men with premature coronary artery disease. Compared to age-matched controls they were more likely to bear at least one of the rare mutations of the LPL gene and were more likely to have elevated triglycerides, but most markedly so if they were overweight [2].

Some have begun to question whether the benefits of dietary manipulation $[3,4]$ and weight loss apply to everyone [5]. Indeed, a change in diet, energy intake or output will have varying effects depending on a variety of largely unknown 'constitutional' factors.

The effects of weight loss on a variety of lipid parameters has been quantified in a recent meta-analysis of 70 studies [6]. The results suggest that for every $\mathrm{kg}$ decrease in body weight there is a predicted decrease of $0.05 \mathrm{mmol} / 1$ in triglycerides and a $0.02 \mathrm{mmol} / 1$ decrease in low density lipoprotein (LDL). In other large studies, such as the multiple risk factor intervention trial (MRFIT), the effects of weight loss and changes in dietary fat composition were additive, with a 3.8-fold greater decrease in plasma cholesterol in the tertile of men with the greatest decrease in Keys score and greatest weight loss compared to men in the tertile of least decrease in Keys score and gain in weight [7].

Unfortunately most previous studies on the determinants of hyper- and hypo-responsiveness have treated weight loss as a confounder rather than as an independent variable in its own right. Given our previous findings from the ECTIM [1] and EARS [2] studies and a body of literature which has focused mainly on the interaction between diet constitution and the genetic predictors of the hypocholesterolemic response, we have studied the influence of specific genetic polymorphisms on the hypolipidemic response to weight loss. Our specific null hypotheses related to polymorphisms of the apolipoprotein B gene (ApoB/VNTR), the LPL gene (LPLSer447-Ter and LPLASP291-Ser mutations) and apo E.

\section{Methods}

Our intention was to recruit patients from primary and secondary care who had been referred to our team for the management of their lipid disorder. In accordance with our Ethical committee's approval, our subjects were enrolled on the basis of a pragmatic trial of dietary intervention before considering pharmacological intervention. Thus following initial screening, subjects received advice on only one intervention diet (i.e. there was no switchback diet), after 12 weeks of which, response was assessed.

Ethical approval for the study was granted by the Queen's University of Belfast Research Ethics Committee.

\subsection{Recruitment criteria and nutritional assessment procedures}

Subjects not already on lipid lowering medication, with a plasma total cholesterol above $7 \mathrm{mmol} / \mathrm{l}$ or a triglyceride greater than $2.5 \mathrm{mmol} / 1$ and a BMI in excess of $27 \mathrm{~kg} / \mathrm{m}^{2}$ were eligible for inclusion. They were recruited mainly from the lipid clinic at the Royal Victoria Hospital, Belfast and from referrals of healthy subjects who had previously served as controls in other recent MONICA project-based studies (catchment population 500 000). Subjects with a personal or family history of tendon xanthomata or other stigmata of familial hypercholesterolaemia were excluded.

An initial fasting blood sample was taken at the lipid clinic but subjects were then called back 1 week later when a second sample was obtained. Only if both samples fulfilled the recruitment criteria were subjects finally enrolled in the study. Subsequently, the average of these first two measurements of lipid parameters was taken as the baseline value.

Each subject completed an interview administered socio-demographic, lifestyle and medical history questionnaire. All subjects were then seen by the nutritionist for an assessment of habitual diet and an individual dietary 'prescription' for the intervention period.

The dietary intervention involved lipid lowering weight and reduction advice and a 12 week follow-up period with two further dietary assessments. At the first clinic visit participants were asked to record their habitual diet using a 4 day estimated food diary. Where portion sizes were unknown they were estimated using UK Ministry of Agriculture, Fisheries and Foods (MAFF) tables [8]. The diaries were then coded and analysed for nutrient intake using the FOODBASE nutrient database [9]. Total daily energy expenditure was calculated as the sum of basal metabolic rate, the thermic effect of food eaten and the energy expended in physical activity [10-12]. The calorific value of the intervention diet was calculated at 500-1000 kcal below these requirements. Dietary guidelines were based on those of the European Atherosclerosis Society [13], less than $30 \%$ energy from total fat (including alcohol); less than $10 \%$ energy from saturates; $10 \%$ energy from polyunsaturates and $10-15 \%$ from monounsaturates; less than $300 \mathrm{mg} /$ day from dietary cholesterol.

Participants were visited in their homes by the dietician three to four times over the intervention period. 
Subjects were weighed on these home visits and given instruction to complete two further food diaries during weeks 4 and 12. Practical advice and behavioural therapy information was given to subjects where appropriate, to increase compliance e.g. advice on regular meal patterns, food shopping, cooking and eating out.

At a final clinic visit the last food diary was checked prior to analysis and BMI recorded.

\subsection{Lipid, lipoprotein and apolipoprotein measurements}

A blood sample of $20 \mathrm{ml}$ was obtained after the subjects had fasted for at least $10 \mathrm{~h}$, and placed in tubes containing $\mathrm{Na}_{2}$ EDTA, kept at room temperature and centrifuged within $4 \mathrm{~h}$. After addition of preservative (final concentrations, EDTA, $0.27 \mathrm{mmol} / 1$; $\varepsilon$-amino-ncaproic acid, $0.9 \mathrm{mmol} / 1$; chloramphenicol, $0.6 \mathrm{mmol} / \mathrm{l}$; and glutathione, $0.3 \mathrm{mmol} / \mathrm{l}$ ) [14], the plasma was stored at $4^{\circ} \mathrm{C}$ for no longer than 6 days and sent at $4^{\circ} \mathrm{C}$ to the laboratory in Lille where lipoprotein measurements were performed immediately.

Table 1

Primers and ASO probes ${ }^{\mathrm{a}}$

Primers used for amplification

Allele specific oligonucleotides

ApoB/VNTR

(u)

GGACAGTGAAACGAGGGC

(1)

GGCACATGAAGACACCAGA

GG

$1.5 \mathrm{mM} \mathrm{MgCl}_{2}$ at $59^{\circ} \mathrm{C}$
Apo $E$

(u) TCCAAGGAGCTGCAGG CGGCGCA

(1) TAGCGCCTGGCCGGCCA GGGAG

$1.5 \mathrm{mM} \mathrm{MgCl}_{2}$ at $65^{\circ} \mathrm{C}$

Codon 112
1. ${ }^{\prime \prime}$ GGACGTGTGCGG
$\mathrm{CCG}^{3 \prime}$
2. ${ }^{5 \prime}$ GGACGTGCGCGG
$\mathrm{CCG}^{3 \prime}$
Codon 158
1. ${ }^{5 \prime}$ GCAGAAGCGCCT
$\mathrm{GGC}^{3 \prime}$
2. ${ }^{5 \prime} \mathrm{GCAGAAGTGCCT}^{\text {GGC }}{ }^{3 \prime}$

LPL 447

(u) TGTTCTACATGGCATATT $1 .{ }^{5 \prime}$ TAAGAAGTCAGGCT CAC

(1) TCAGGATGCCCAGTCA GCTT

$1.5 \mathrm{mM} \mathrm{MgCl}_{2}$ at $55^{\circ} \mathrm{C}$

LPL 291

(u) TTATTTACAACAGTCTC CAG

(l) AtCtTGgtgtctCTtTT TTACC

$3.5 \mathrm{mM} \mathrm{MgCl}_{2}$ at $55^{\circ} \mathrm{C}$

\section{2. ${ }^{5 \prime}$ TGACTTTACTGATC \\ 1. ${ }^{5 \prime}$ TGAGATCAATAAAG $\mathrm{TCA}^{3}$} 2. ${ }^{5 \prime}$ TAAGAAGTGAGGCT GGT $^{3 \prime}$
Initial plasma total cholesterol and triglycerides were measured in the Department of Clinical Biochemistry, Royal Victoria Hospital, by enzymatic methods (Boehringer Mannheim, Mannheim, Germany) adapted to a Hitachi 705 analyser. The Institut Pasteur in Lille subsequently measured cholesterol in the very low density lipoprotein (VLDL) fraction separated by ultracentrifugation [15] and in the high density lipoprotein (HDL) - containing supernatant after sodium phosphotungstate/magnesium chloride precipitation (Boehringer Mannheim). Low density lipoprotein (LDL) cholesterol was estimated by subtraction. Apolipoproteins (apos) A-I and B were quantified by immunonephelometry (Behringwerke, Marburg, Germany). The inter-assay coefficients of variation for cholesterol, triglyceride, high density cholesterol and apoB, the primary endpoints of interest in this study, were $1.34,1.78,4.43$ and $3.95 \%$, respectively. Lipid results were unavailable from Lille for 17 samples $(3.9 \%)$ in 14 individuals. We substituted values derived from assays performed locally in Belfast after adjustment for inter-laboratory bias. As samples had been independently assayed in Belfast throughout the study, this bias was investigated by paired $t$-tests and BlandAltman plots on the remaining data-set. The correction was an additive factor for cholesterol, LDL and HDL and a multiplicative factor for triglyceride. The adjusted values for these 17 samples were then used in the final analysis.

\subsection{Extraction of genomic DNA and genotyping}

Genomic DNA was extracted from white blood cells using the 'salting out' procedure described by Miller et al. [16]. The polymerase chain reaction (PCR) was used to amplify the regions encompassing the ApoB/VNTR, ApoE, LPLSer447-Ter mutation and LPLASP291-Ser mutations. A description of these polymorphisms and amplimers is provided in the table below.

All biallelic polymorphisms were analysed by hybridisation of the corresponding amplification products with allele specific oligonucleotides (ASO). The sequences of ASO probes are provided below. The ASO $(10 \mathrm{pmol})$ probes were phosphorylated at their $5^{\prime}$ ends with $\gamma^{32} \mathrm{P}$ dATP $(3000 \mathrm{Ci} / \mathrm{mmol})$ and $\mathrm{T}_{4}$ polynucleotide kinase (GIBCO BRL, UK). Membranes were prehybridised for $3 \mathrm{~h}$ in a hybridisation buffer containing PEG $7 \%$ and SOS $10 \%$. For each polymorphism, hybridisation with the ASO probe corresponding to the less frequent allele was performed for $3 \mathrm{~h}$ and autoradiograms were prepared by exposing films (Dupont) to membranes at $-20^{\circ} \mathrm{C}$ for $4-12 \mathrm{~h}$. Membranes were then dehybridised, and rehybridised using the same procedures with the ASO probe corresponding to the most frequent allele and autoradiograms prepared Table 1.

\footnotetext{
${ }^{\text {a }} 1$, More frequent allele; 2 less frequent allele.
} 
Table 2

Baseline lipid and lipoprotein variables and absolute change after intervention

\begin{tabular}{lccccc}
\hline & Mean & S.D. & Missing & Absolute change (S.D.) after dietary intervention \\
\hline Total cholesterol $(\mathrm{mm} / \mathrm{l})$ & 7.58 & 1.12 & 1 & $-0.46(0.95)$ & 2 \\
High density cholesterol $(\mathrm{mm} / \mathrm{l})$ & 1.12 & 0.28 & 1 & $-0.03(0.17)$ & 2 \\
Low density cholesterol $(\mathrm{mm} / \mathrm{l})$ & 5.00 & 0.99 & 1 & $-0.29(0.82)$ & 2 \\
Triglyceride $(\mathrm{mm} / \mathrm{l})$ & 3.43 & 2.50 & 1 & $-0.44(1.77)$ & 2 \\
Apo B $(\mathrm{g} / \mathrm{l})$ & 1.90 & 0.40 & 5 & $-0.12(0.30)$ & 13 \\
\hline
\end{tabular}

Table 3

Bivariate correlation of weight change after intervention with change in dietary constituents and lipids

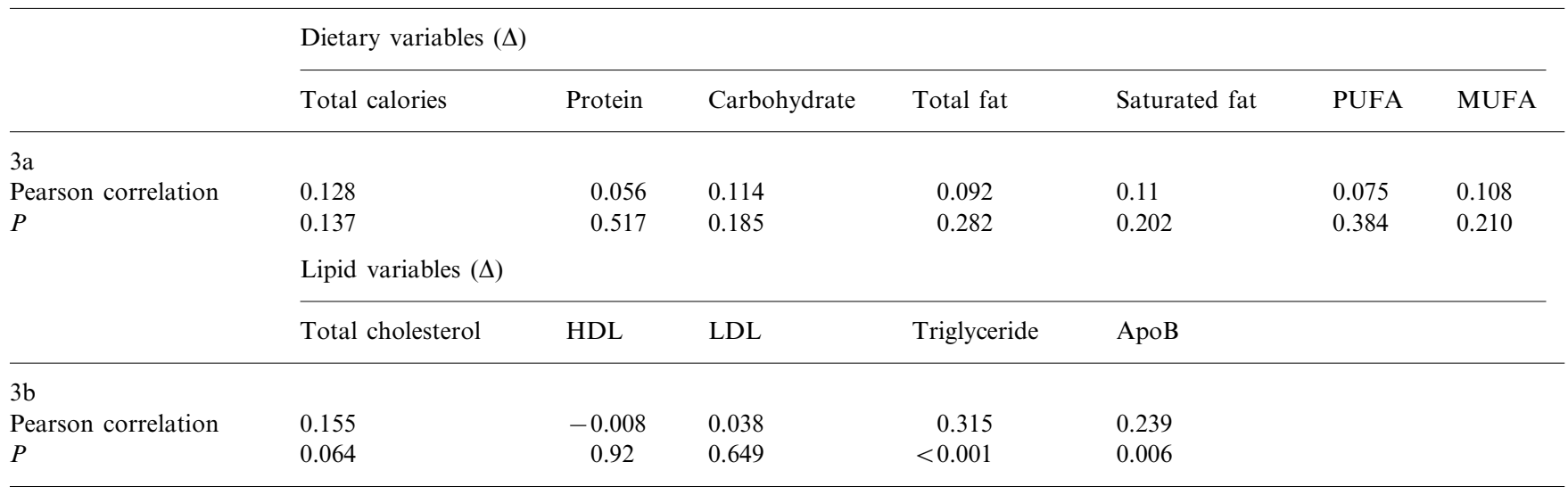

\subsection{Statistical methods}

The key outcome variables of interest were the changes in lipid parameters (primarily, total cholesterol, HDL cholesterol, LDL cholesterol, triglycerides, and apolipoprotein B) after the 12 week intervention diet. The key independent variable was the change in body weight, with genotype, age, initial BMI and gender as the principal co-variates. Our analytic strategy was to adjust for specific dietary component changes only if significant overall effects of genetic constitution on the relationship between weight loss and lipid change were observed.

Multiple regression was used to compare the slopes of the relationships between change in lipid (\%) and change in weight $(\%)$ in subgroups defined by genotypes. In each case, checks were first undertaken for Hardy-Weinberg equilibrium. Among all the genotypes tested, the only significant departure from equilibrium proportions was for $\mathrm{ApoE}(\varepsilon 2)$, where there was a significant over-representation of the $\varepsilon 22$ allele. This is not entirely surprising given our recruitment criteria (specifying a mixed hyperlipidaemia pattern) and is due to the over-representation in this referral sample of subjects with Type III hyperlipidaemia. [The number of subjects in each apo $\varepsilon$ genotype class were, $\varepsilon 22$ (4); $\varepsilon 23$ (13); $\varepsilon 33$ (68); $\varepsilon 34$ (51); $\varepsilon 24$ (2); $\varepsilon 44$ (4)].

Because of relatively small numbers it was decided to undertake a two-level genotype comparison, combining homozgyotes with heterozygotes for the rarer allele into one group. Results are expressed as the difference in slope coefficients between the genotypic subgroups.

\section{Results}

Although our target had been to recruit 200 subjects, the rate of recruitment fell substantially and dramatically after the publication of the 4S [17] and WOSCOPS [18] findings. One hundred and forty six subjects were recruited in total (70 men and 76 women). The mean age of the group was 51.2 years (S.D. 9.82) [46.8 (S.D. 9.4) for men and 55.2 (S.D. 8.4) for women] and the mean BMI 30.9 (S.D. 3.16). The group, as a whole, was relatively 'healthy', only two $(1.4 \%)$ having previously had a diagnosis of myocardial infarction, though $66(45.2 \%)$ had a previous diagnosis of hypertension. The average weight loss was $3.15 \mathrm{~kg}$ overall [with a range from $-4.8 \mathrm{~kg}$ (i.e. a gain) to $14.9 \mathrm{~kg}$ ], although 13 subjects gained weight. Table 2 gives their initial lipid parameters, (the mean of the first two measurements prior to the intervention diet).

The change achieved in the intake of particular constituents of the diet varied. Total calorie intake, for example, fell by $16 \%$ and total fat by $29 \%$, with a corresponding decrease in carbohydrate of $9 \%$.

The change achieved in body weight was initially correlated with the change in the dietary and lipid and 


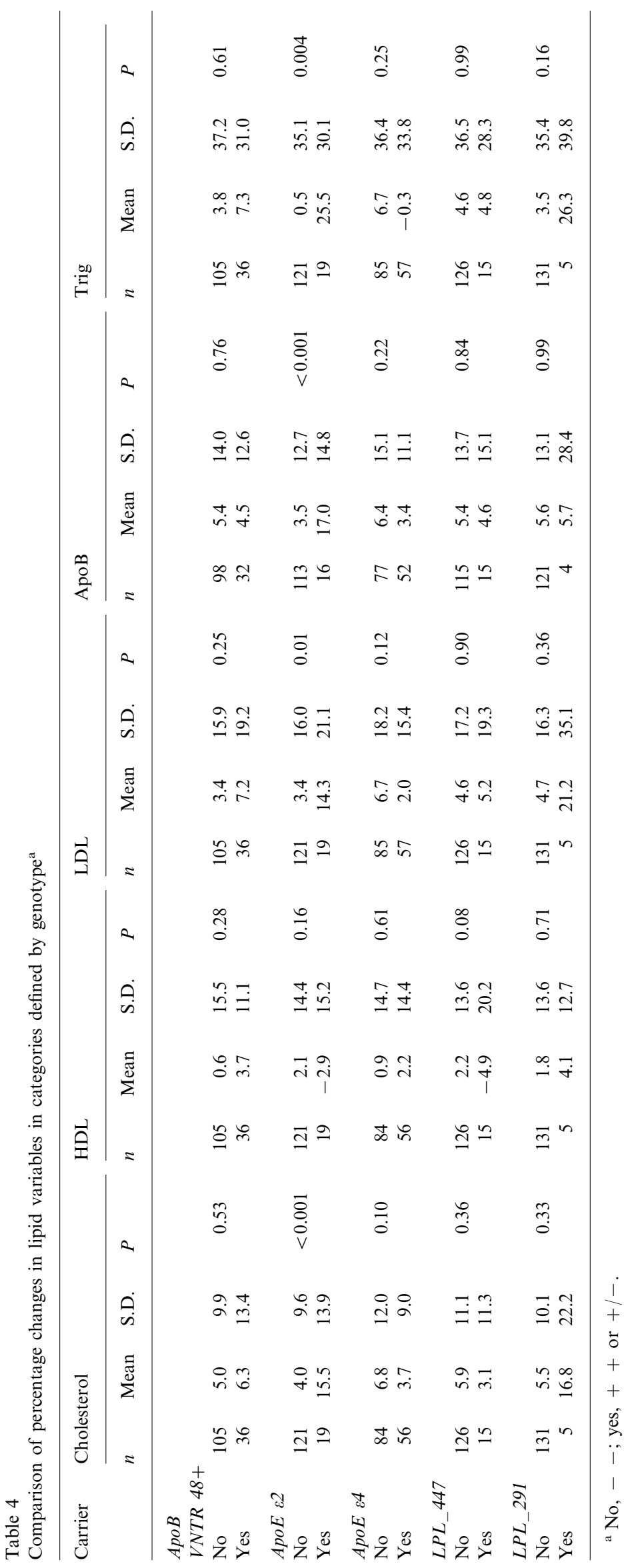


lipoprotein variables. Table 3 gives these initial bivariate correlations. There were significant correlations between the degree of weight change and ApoB and triglyceride levels after intervention. There was no significant correlation between the degree of weight loss and the percentage change in the various dietary constituents.

Table 4 gives the mean change in lipid parameters across genotype classes. From this table there is the suggestion that after the intervention, cholesterol, LDL, ApoB and triglyceride levels have changed more among subjects with at least one apos2 allele and less among those with at least one $\varepsilon 4$ allele.

\subsection{The influence of genotype on the relationship between weight change and lipid change}

While Table $3 b$ indicates the overall association between weight change and lipid change, the key test is a comparison of the slope coefficients for each genotype concerned $\{(++$ and $+/-)$ vs. $(--)$ for the rare and common alleles\}. Tables 5-7 summarise these results. Figs. 1 and 2 more clearly illustrate the approach taken. In this regression analysis, BMI is the main independent variable contrary to the approach of many previous studies. For most of the major traits considered (total cholesterol, HDL, LDL, apolipoprotein B and triglyceride), there was no statistically significant difference in the slope of the relationship between weight reduction and lipid change for any of the genotypes studied. The sole exceptions to this were for apos4. In this instance, there was a significantly reduced responsiveness to weight loss demonstrated for both total cholesterol and apolipoprotein B among subjects with at least one $\varepsilon 4$ allele. The final column of Tables 4-6 gives the difference in slopes and its 95\% confidence intervals. From this one might judge whether the results could exclude a minimum clinically important difference in the lipid reduction after weight loss (of a given degree) between subjects of one or other genotype.

Table 5

Slope coefficients relating weight change to lipid response for apoB

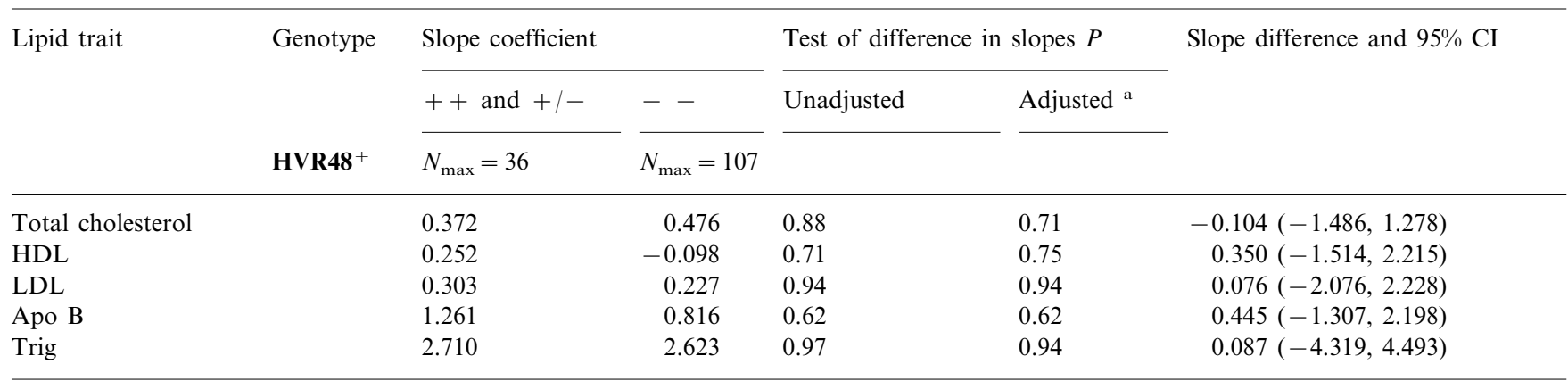

${ }^{\text {a }} P$ adjusted for age, gender and initial BMI.

Table 6

Slope coefficients relating weight change to lipid response for ApoE genotypes

\begin{tabular}{|c|c|c|c|c|c|c|}
\hline \multirow[t]{2}{*}{ Lipid trait } & \multirow{2}{*}{$\begin{array}{l}\text { Genotype } \\
\text { Apo } \varepsilon 2\end{array}$} & \multicolumn{2}{|l|}{ Slope coefficient } & \multicolumn{2}{|c|}{ Test of difference in slopes $P$} & \multirow[t]{2}{*}{ Slope difference and $95 \% \mathrm{CI}$} \\
\hline & & ++ and $+/-$ & -- & Unadjusted & Adjusted $^{\mathrm{a}}$ & \\
\hline Total cholesterol & & 1.337 & 0.328 & 0.22 & 0.22 & $1.009(-0.627,2.645)$ \\
\hline HDL & & 0.401 & -0.039 & 0.71 & 0.74 & $0.441(-1.905,2.786)$ \\
\hline \multirow[t]{2}{*}{ Trig } & & 4.263 & 2.297 & 0.47 & 0.49 & $1.965(-3.412,7.343)$ \\
\hline & Apo $\varepsilon 4$ & $N_{\max }=57$ & $N_{\max }=85$ & & & \\
\hline Total cholesterol & & -0.004 & 1.084 & 0.03 & 0.04 & $-1.087(-2.09,-0.084)$ \\
\hline HDL & & -0.473 & 0.507 & 0.16 & 0.13 & $-0.978(-2.353,0.393)$ \\
\hline
\end{tabular}

\footnotetext{
a Adjusted for age, gender and initial BMI.
} 
Table 7

Slope coefficients relating weight change to lipid response for LPL genotypes

\begin{tabular}{|c|c|c|c|c|c|c|}
\hline \multirow[t]{2}{*}{ Lipid trait } & \multirow{2}{*}{$\begin{array}{l}\text { Genotype } \\
\text { LPL447 }\end{array}$} & \multicolumn{2}{|l|}{ Slope coefficient } & \multicolumn{2}{|c|}{ Test of difference in slopes $P$} & \multirow[t]{2}{*}{ Slope difference and $95 \% \mathrm{CI}$} \\
\hline & & ++ and $+/-$ & -- & Unadjusted & Adjusted $^{\mathrm{a}}$ & \\
\hline \multirow{3}{*}{$\begin{array}{l}\text { Total cholesterol } \\
\text { HDL } \\
\text { Trig }\end{array}$} & & 1.867 & 0.311 & 0.10 & 0.11 & $1.556(-0.322,3.434)$ \\
\hline & & 0.727 & -0.083 & 0.52 & 0.58 & $0.810(-1.669,3.289)$ \\
\hline & LPL 291 & $N_{\max }=5$ & $N_{\max }=133$ & & & \\
\hline \multirow{3}{*}{$\begin{array}{l}\text { Total cholesterol } \\
\text { HDL } \\
\text { Trig }\end{array}$} & & -0.2665 & 0.402 & 0.63 & 0.73 & $-0.667(-3.366,2.032)$ \\
\hline & & 1.713 & -0.123 & 0.29 & 0.37 & $1.835(-1.591,5.262)$ \\
\hline & & -0.661 & 2.550 & 0.47 & 0.53 & $-3.211(-11.918,5.496)$ \\
\hline
\end{tabular}

a Adjusted for age, gender and initial BMI.

For example, although subjective, one might consider a difference in slopes of $2.5 \%$ as the minimum clinically important for total cholesterol as this would translate into a risk difference (assuming it was sustained) of around $5 \%$. An effect of this size is compatible with that demonstrated for the relationship between apos4 and apolipoprotein $\mathbf{B}$.

\section{Discussion}

In terms of the magnitude of the change in lipid traits, such as total cholesterol, consequent upon a reduction in weight of $1 \mathrm{~kg}$, the overall results of this study are broadly consistent with the findings of a recent meta-analysis [6]. In the MRFIT study, [7] correlations relating change in weight to change in lipids were substantially greater than those relating the change in lipids to the change in the dietary (keys) score, prompting some to conclude that it may be more important for hyperlipidaemics to lose weight than to change the fat composition of their diet [19].

Among our primary objectives had been to determine whether there was any differential effect of weight loss on lipid change in subgroups defined by particular alleles or genotypes (in particular by VNTR polymorphisms of the apoB gene, two mutations of the LPL gene and apoE). For most of the genotypes studies this has not been demonstrated and there are at least four possible interpretations.

The genotypes studied may exert no true effect on the variability of lipid response to weight loss. Most other studies in this area have reported their findings in terms of how genetic factors modify the hypocholesterolemic response to dietary change and the observed magnitude of this effect has varied. In one study for example, allele frequencies (of polymorphisms of the apoB gene) were shown to differ significantly between 'responders' and 'non-responders' on the basis of a 3\% difference in cholesterol after dietary intervention [20]. Other studies have assessed the proportion of variance in lipid response that can be explained by constitutional factors.

A significant difficulty in interpreting the findings of these studies is the inability to distinguish hypothesis confirming from hypothesis generating findings that have emerged from post hoc data dredging. In some studies, the finding of a variability gene effect may be linked to one specific lipid endpoint but not another, while later findings may fail to corroborate earlier ones. For example, Humphries et al. [21] were unable to replicate their earlier finding linking the wild-type allele

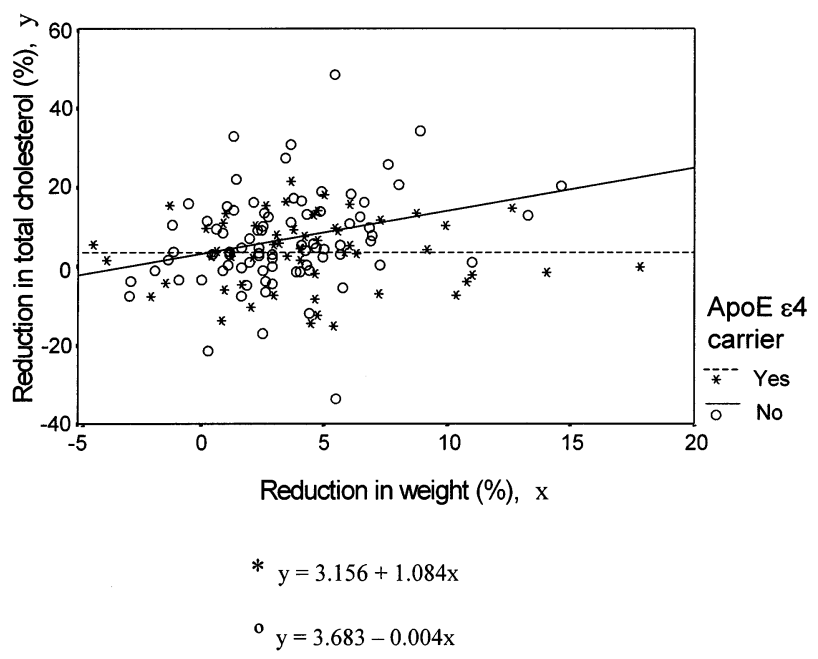

Test to compare slopes:

$t=2.14, d f=136 ; p=0.034$

Test to compare slopes (adjusted for age, gender and baseline BMI):

$\mathrm{t}=2.12, \mathrm{df}=133 ; \mathrm{p}=0.036$

Fig. 1. Relationship between change in total cholesterol and change in weight by apoE $\varepsilon 4$ carrier status. 


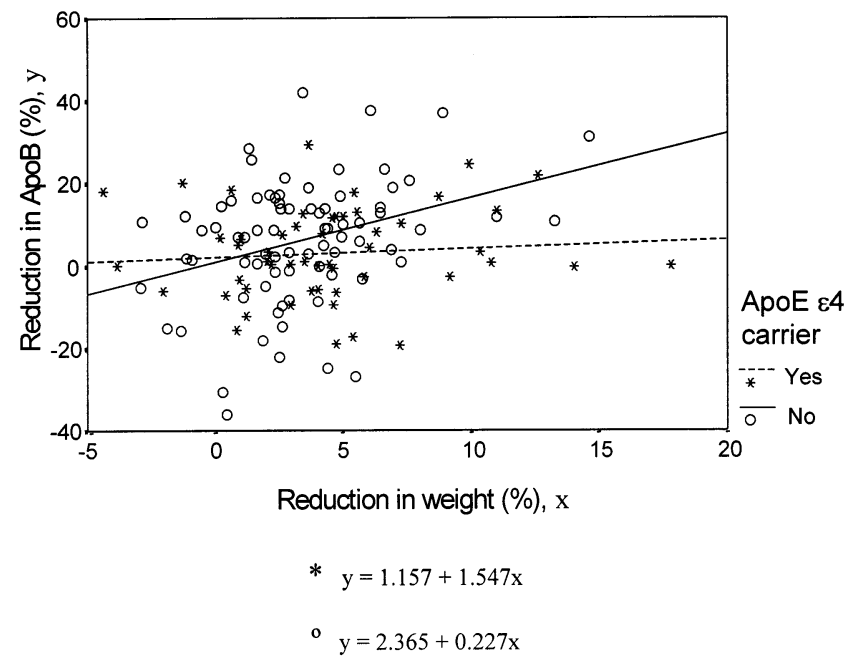

Test to compare slopes:

$t=2.06, d f=125 ; p=0.04$

Test to compare slopes (adjusted for age, gender and baseline BMI):

$\mathrm{t}=1.88, \mathrm{df}=122 ; \mathrm{p}=0.06$

Fig. 2. Relationship between change in apoB and change in weight by apoE $\varepsilon 4$ carrier status.

of the apoB gene signal peptide to hyper-responsiveness to dietary change. Sometimes disparate findings and different analytic strategies are reported from a single study population (such as those from the North Karelia Dietary Intervention Study by Tikkanen and colleagues [22-25])

An alternative explanation is that our study had insufficient power to detect a true effect. While this may be the case, our study remains one of the largest of its kind to date [26-49]. Making at least one repeat measurement at baseline, as we have done, can reduce the impact of regression to the mean and improve power to dissect inter-individual differences [50]. None of the previous studies specifically focused on weight change. However, smaller studies than ours have demonstrated a significant relationship between genetic factors, dietary change and the hypocholesterolaemic response. However, if 'negative' studies of comparable size have not been submitted or accepted for publication, then it is possible that some of the previously positive studies can be accounted for by Type I error.

We have found that there was a significantly blunted responsiveness to weight loss among subjects with at least one $\varepsilon 4$ allele. The effect size, nevertheless, is of modest magnitude. Some smaller studies have found either no effect or that subjects with at least one $\varepsilon 4$ allele are more likely to be hyper-responders to dietary change. Nevertheless our findings are similar to those of Sarkkinen in a study of comparable size to our own [46].
An alternative explanation for our findings might be that a true effect of 'variability' genes exists but that the short-term and long-term effects are different. Most previous studies have been short term but data from twin studies [51] and from longitudinally followed cohorts (such as the cardiovascular risk in Young Finns study [52]) suggest the operation of longer-term geneenvironment interactions.

Finally, it may be naïve to posit an effect which is not context or population dependent. The habitual diet or the varying allele prevalence of the genes involved in metabolic regulation might all contribute to disparate findings in different populations [53]. Ordovas found, for example that in studies which had successfully reduced the total fat in the diet, $\varepsilon 4$ subjects were more likely to be hyper-responders; whereas in studies that modified the saturation rather than the fat amount, $\varepsilon 4$ subjects were more likely to be hypo-responders but his review was unable to control for weight loss (and in most cases the data were not available) [53]. However, adjustment for factors on the same causal pathway could be viewed as over-adjustment and so the task becomes even more daunting, considering the potential for gene-gene interaction and the likelihood of dietary regulation of gene expression.

The present study, perhaps uniquely, has focused on the effect of weight loss on plasma lipids and how this might be modulated by constitutional factors. Other investigations of diet-gene interaction have studied the relationship between particular dietary change and changes in lipid levels, adjusting for changes in body weight or BMI [23]. While one might be seduced into 'dredging' the data for associations not previously specified, we have not attempted to test null hypotheses that were not directly related to the findings, which gave this study its birth. We are unable to reject the null hypothesis of no differential effect of weight loss on plasma lipids in genetically defined subgroups in our hospital clinic population.

Convincing evidence has been presented from numerous trials and observational studies that a calorie-controlled low saturated-fat diet that is rich in fruit and vegetables can reduce mortality [54]. Even if the present study had demonstrated that subgroups of patients (who were likely to respond better to weight reduction) could be identified by a simple genetic test, we are unsure how such knowledge would affect their referral and management practice. We doubt whether the degree of blunted responsiveness, which we found among carriers of $\varepsilon 4$ might be large enough to change clinical practice.

Recently the UK Department of Health has itself issued guidance on the appropriate place of genetic 'susceptibility' testing [55]. Aside from the difficult issues surrounding consent, several basic tests of scientific and clinical validity should be applied before offering 
such tests. Of relevance here is (i) the requirement that the genetic change sought is causally related to the disorder; and (ii) the importance of considering how phenotypic variability may be dependant on specific types of mutations, other genes and other co-variates such as age. For very few candidate genes of relevance to cardiological practice have such issues been satisfactorily resolved. Our own findings re-inforce the view that it would be premature to offer targeted lifestyle advice based on the sorts of susceptibility-genotype associations that have been published to date, many of which have been uncovered through post hoc analyses.

\section{Acknowledgements}

This study was funded by the UK Department of Health's Research and Development Directorate (DC15). The study was also supported by INSERM SC7 and by the Institut Pasteur, Lille.

\section{References}

[1] Weston JE, Moreel JFR, McMaster D, Cambou JP, Luc G, Parra HG, Tiret L, et al. An association of body mass index with myocardial infarction in individuals with a polymorphism of the apoB gene. Ir J Med Sci 1993;162(11):30.

[2] Gerdes C, Fisher R, Nicaud V, Boer J, Humphries S, Talmud P, et al. Lipoprotein lipase variants D9N and N291S are associated with increased plasma triglyceride and lower HDL cholesterol concentrations. Circulation 1997;96:733-40.

[3] Howell WH, McNamara D, Tosca M, Smith BT, Gaines JA. Plasma lipid and lipoprotein responses to dietary fat and cholesterol: a meta-analysis. Am J Clin Nutr 1997;65:1747-64.

[4] Ramsay LE, Yeo WW, Jackson PR. Dietary reduction of serum cholesterol concentration: time to think again. $\mathrm{Br}$ Med $\mathrm{J}$ 1991;303:953-7.

[5] Kassirer JP, Angell M. Losing weight - an ill fated New Year's resolution. New Engl J Med 1998;338:52-4.

[6] Datillo A, Kris-Etherton PM. Effects of weight reduction on blood lipids and lipoproteins: a meta-analysis. Am J Clin Nutr 1992;56:320-8.

[7] Stamler J, Briefel R, Milas C, Grandits G, Caggiula A. Relation of changes in dietary lipids and weight, trial years $1-6$, to changes in blood lipids in the special intervention and usual care groups in MRFIT. Am J Clin Nutr 1997;65:272S-88S.

[8] Ministry of Agriculture Fisheries and Food. Food portion sizes, 2nd ed.

[9] World Health Organisation. Energy and Protein Requirements. Report of a joint FAO/WHO/UNU meeting, Geneva: World Health Organisation, 1985. WHO Technical Report Series 724.

[10] Dietary Reference Values for Food Energy and Nutrients for the UK. Report of the panel on DRVs of the Committee on Medical Aspects of Food Policy. Department of Health, 1991 (HMSO).

[11] Schofield NN, Schofield C, James WPT. Basal metabolic rate review and publication. Hum Nutr Clin Nutr 1985;39:1-96.

[12] Dietary Reference Values for Food Energy and Nutrients for the UK. Report of the panel on DRVs of the Committee on Medical Aspects of Food Policy. Department of Health, 1991 (HMSO).

[13] European Atherosclerosis Society. Prevention of Coronary Heart Disease Scientific Background and New Clinical Guidelines, 1992.
[14] Lee DM, Valente AJ, Kuo WH, Maeda H. Properties of apolipoprotein B in urea and in aqueous buffers: the use of glutathione and nitrogen in its solubilization. Biochim Biophys Acta 1981;666:133-46.

[15] Alaupovic P, Lee DM, McConathy WJ. Studies on the composition and structure of plasma lipoproteins: distribution of lipoprotein families in major density classes of normal human plasma lipoproteins. Biochim Biophys Acta 1972;260:689-707.

[16] Miller SA, Dykes DD, Polesky HF. A simple salting out procedure for extracting DNA from human nucleated cells. Nucleic Acid Res 1988;16:1215-8.

[17] Randomised trial of cholesterol lowering in 4444 patients with coronary heart disease: the Scandinavian Simvastatin Survival Study (4S). Lancet 1994;344(8934):1383-1389.

[18] Shepherd J, Cobbe SM, Ford I, Isles CG, Lorimer AR, MacFarlane PW, et al. Prevention of coronary heart disease with pravastatin in men with hypercholesterolemia. West of Scotland Coronary Prevention Study Group. New Engl J Med 1995;333(20):1301-7.

[19] Jansen S, Lopez-Miranda J, Salas J, Castro P, Paniagua J, Lopez-Segura F, et al. Plasma lipid reposne to hypolipidaemic diets in young healthy non-obese men varies with body mass index. J Nutr 1998;128:1144-9.

[20] Abbey M, Belling B, Clifton P, Nestel P. Apolipoprotein B gene polymorphism associates with plasma cholesterol changes induced by dietary fat. Nutr Metab Cardiovasc Dis 1991;1:10-2.

[21] Humphries S, Talmud P, Cox C, Sutherland W, Mann J. Genetic factors affecting the consistency and magnitude of changes in plasma cholesterol in response to dietary challenge. Q J Med 1996;89:671-80.

[22] Tikkanen MJ, Huttenen JK, Enholm C, Pietinen P. Apolipoprotein $\mathrm{E} 4$ homozygosity predisposes to serum cholesterol elevation during high fat diet. Arteriosclerosis 1990;10:285-8.

[23] Talmud P, Boerwinkle E, Xu CF, Tikkanen M, Pietinen P, Huttunen J, Humphries S, et al. Dietary intake and gene variation influence the response of plasma lipids to dietary intervention. Genet Epidemiol 1992;9:249-60.

[24] Tikkanen MJ, Xu CF, Hamalainen T, Talmud P, Sarna S, Huttenen JK, et al. XbaI polymorphism of the apolipoprotein B gene influences plasma lipid response to diet intervention. Clin Genet 1990;37:327-34.

[25] Xu CF, Boerwinkle E, Tikkainen MJ, Huttenen JK, Humphries SE, Talmud P. Gentic variation at the apolipoprotein gene loci contribute to response of plasma lipids to dietary change. Genet Epidemiol 1990;7:261-75.

[26] Friedlander Y, Berry E, Eisin berg S, Stein Y, Leitersdorf E. Plasma lipids and lipoproteins response to a dietary challenge: analysis of four candidate genes. Clin Genet 1995;47:1-12.

[27] Ilmonen M, Helio T, Butler R, Palotie A, Pietinen P, Huttunen $\mathrm{J}$, et al. Two new immunogenetic polymorphisms of the apoB gene and their effect on serum lipid levels and responses to changes in dietary fat intake. Arterioscler Thromb Vasc Biol 1995; 15:1287-93.

[28] Humphries S, Talmud P, Cox C, Sutherland W, Mann J. Genetic factors affecting the consistency and magnitude of changes in plasma cholesterol in response to dietary challenge. Q J Med 1996;89:671-80.

[29] Pajukanta P, Valsta L, Aro A, Pietinen P, Helio T, Tikkanen M. The effects of apolipoprotein B signal peptide and XbaI polymorphism on plasma lipid responses to dietary change. Atherosclerosis 1996;122:1-10.

[30] Miettinen TA, Gylling H, Vanhanen H. Serum cholesterol response to dietary cholesterol and apoprotein $\mathrm{E}$ phenotype. Lancet 1988;2:1261.

[31] Manttari M, Koskinen P, Enholm C, Huttunen JK, Manninen V. Apolipoprotein E polymorphism influences the serum cholesterol response to dietary intervention. Metabolism 1991;40:21721. 
[32] Savolainen MJ, Rantala M, Kervinen K, Jarvi L, Suvanto K, Rantala $\mathrm{T}$, et al. Magnitude of dietary effect on plasma cholesterol concentration: role of sex and apoE phenotype. Atherosclerosis 1991;86:145-52.

[33] Glatz J, Demacker P, Turner P, Katan M. Response of serum cholesterol to dietary cholesterol in relation to apolipoprotein $\mathrm{E}$ phenotype. Nutr Metab Cardiovasc Dis 1991;1:13-7.

[34] Fisher EA, Blum CB, Zannis VI, Breslow JL. Independent effects of dietary saturated fat and cholesterol on plasma lipids, lipoproteins and apolipoprotein E. J Lipid Res 1983;24:1039-48.

[35] Clifton PM, Keston M, Abbey M, Drysdale M, Nestel PJ. Relationship between sensitivity to dietary fat and dietary cholesterol. Arteriosclerosis 1990;10:394-401.

[36] Tikkanen MJ, Xu CF, Hamalainen T, Talmud P, Sarna S, Huttenen JK, et al. XbaI polymorphism of the apolipoprotein B gene influences plasma lipid response to diet intervention. Clin Genet 1990;37:327-34.

[37] Xu CF, Boerwinkle E, Tikkainen MJ, Huttenen JK, Humphries SE, Talmud P. Genetic variation at the apolipoprotein gene loci contribute to response of plasma lipids to dietary change. Genet Epidemiol 1990;7:261-75.

[38] Lehtimaki T, Frankberg-Lakkala H, Solakivi T, Koivisto AM, Laipalla P, Enholm C, et al. The effect of short term fasting, apolipoprotein E phenotype and sex on plasma lipids. Am J Clin Nutr 1997;66:599-605.

[39] Lopez-Miranda J, Jansen S, Ordovas J, Salas J, Marin C, Castro $\mathrm{P}$, et al. Influence of the SstI polymorphsim at the apolipoprotein CIII gene locus on the plasma low density lipoprotein cholesterol response to dietary monounsaturated fat. Am J Clin Nutr 1997;66:97-103.

[40] Goldberg AC, Cole T, Kitchens R, Schechtman K, Schonfeld G. Apolipoprotein $\mathrm{E}$ phenotype affects response to dietary perturbation. Cirulation 1987;76:4-34.

[41] Brenninkmeijer BJ, Stuyt P, Demacker P, Stalenhoef A, van't Laar A. Apo E polymorphism and lipoprotein concentrations during a cholesterol rich diet. Arteriosclerosis 1987;7(5):516a.

[42] McCombs R, Marcadas DE, Ellis J, Weinberg R. Attenuated hypercholesterolaemic response to a high cholesterol diet in subjects heterozygous for the apolipoprotein AVI-2 allele. New Engl J Med 1994;331:706-10.

[43] Lehtimaki T, Moilanen T, Solakivi T, Laippala P, Enholm C. Cholesterol rich diet induced changes in plasma lipids in relation to apolipoprotein E phenotype in healthy subjects. Ann Med 1992;24:61-6.

[44] Miettinen TA, Gylling H, Vanhanen H, Ollus A. Cholesterol absorption, elimination and synthesis related to LDL kinetics during varying fat intake in men with different apoprotein $\mathrm{E}$ phenotypes. Arterioscler Thromb 1992;12:1044-52.

[45] Martin LJ, Connelly PW, Nancoo D, Wood N, Zhang ZJ, Maguire $G$, et al. Cholesteryl ester transfer protein and high density lipoprotein responses to cholesterol feeding in men: relationship to apolipoprotein $\mathrm{E}$ genotype. J Lipid Res 1993;34:437-46.

[46] Sarkkinen ES, Ussitupa M, Pietinen P, Ahola I, Penttila I, Kervinen K, et al. Long term effects of three fat modified diets in hypercholesterolaemic subjects. Atherosclerosis 1994;104:923.

[47] Cobb M, Teitlebaum H, Risch N, Jekel J, Ostfeld A. Influence of dietary fat, apolipoprotein E phenotype and sex on plasma lipoprotein levels. Circulation 1992;86:849-57.

[48] Lefevre M, Ginsberg HN, Kris-Etherton PM, Elmer PJ, Stewart PW, Ershow A, et al. ApoE genotype does not predict lipid response to changes in dietary saturated fatty acids in a heterogeneous normolipidemic population. The DELTA Research Group. Arterioscler Thromb Vasc Biol 1997;17:2914-23.

[49] Zambon D, Ros E, Casals E, Sanllehy C, eBertomeu A, Campero I. Effect of apolipoprotein E polymorphism on the serum lipid response to a hypolipidaemic diet rich in monounsaturated fatty acids in patients with hypercholesterolaemia and hyperlipidaemia. Am J Clin Nutr 1995;61:141-8.

[50] Irwig L, Glasziou P, Wilson A, Macaskill P. Estimating an individual's true cholesterol level and response to intervention. J Am Med Assoc 1991;266:1678-85.

[51] Thorn JA, Needham EW, Mattu RK, Stocks J, Galton DJ. The Ser447-Ter mutation of the lipoprotein lipase gene relates to variability of serum lipid and lipoprotein levels in monozygotic twins. J Lipid Res 1998;39:437-41.

[52] Porkka KV, Taimela S, Kontula K, Lehtimaki T, Aalto-Setala $\mathrm{K}$, Akerblom HK, et al. Variability gene effects of DNA polymorphisms at the apoB, apoAI/CIII and apoE loci on serum lipids: the cardiovascular risk in Young Finns study. Clin Genet 1994;45:113-21.

[53] Ordovas J, Lopez Miranda J, Mata P, Perez-Jimenez F, Lichtenstein A, Schafer E. Gene-diet interaction in determining plasma lipid response to dietary intervention. Atherosclerosis 1995;118:S11-27.

[54] Wood D, De Backer G, Faergeman O, Graham I, Mancia G, Pyorala K. Task force report: prevention of coronary heart disease in clinical practice. Eur Heart J 1998;19:1434-503.

[55] Advisory Committee on Genetic Testing. Genetic Testing for Late Disorders. Health Departments of the United Kingdom, London, 1998. 